\title{
Laparoscopic partial nephrectomy in rats $^{1}$
}

\author{
Nefrectomia parcial laparoscópica em ratos
}

\author{
Fernando Meyer ${ }^{2}$, Sérgio Ossamu Ioshii ${ }^{3}$, Eduardo Wei Kin Chin ${ }^{4}$, Danielle Mussoi Esser ${ }^{5}$, Renata Tomasetti Marcondes ${ }^{5}$, \\ Andressa Hubar Patriani5, Bruno de Figueiredo Pimpão ${ }^{5}$ \\ 1. Research performed at the Experimental Laboratory of Medullar Lesions of Pontifícia Universidade Católica do Paraná (PUCPR) and \\ Department of Urology, Hospital Universitário Cajuru (HUC), Curitiba, Brazil. \\ 2. PhD, Associate Professor, Division of Urology, Surgery Department of PUCPR. Chief of Urology Department HUC, Curirtiba, Brazil. \\ 3. PhD, Full Professor, Division of Pathology, PUCPR. Associate Professor, Department of Pathology, Universidade Federal do \\ Paraná (UFPR), Brazil. \\ 4. MD. Resident, Department of Urology, Irmandade da Santa Casa de Misericórdia de Curitiba (ISCMC), Brazil. \\ 5. Graduate student, PUCPR, Brazil.
}

\begin{abstract}
Purpose: To establish an experimental model of laparoscopic partial nephrectomy (LPN) in rats and to analyze morphological alterations in the renal parenchyma utilizing an electric cautery and harmonic scalpel. Methods: Forty Wistar rats were used, divided in 2 experiments with 20 rats each: experiment I, LPN was performed with an electric cautery and the rats were subdivided into groups A and B; experiment II, LPN was performed with a harmonic scalpel and they were subdivided into groups $\mathrm{C}$ and $\mathrm{D}$. The animals in groups $\mathrm{A}$ and $\mathrm{C}$ were sacrificed shortly after surgery and the remnant kidney was removed to study the following variables: necroses and degeneration. In groups B and D a laparatomy was performed for retrieval of the remnant kidney on the $14^{\text {th }}$ day after surgery to analyze fibrous scarring. Results: For the variables necroses and fibrous scarring, the electric cautery creates, on average, greater width than that produced by the harmonic scalpel $(p=0.0002$ and $p=0.0068$ respectively). Regarding the variable of degeneration, we found no significant difference between the two types of scalpels ( $\mathrm{p}=0.1267)$. Conclusions: $\mathrm{LPN}$ in rats is an adequate and feasible experimental model. The electric cautery caused greater damage to remnant renal tissue when compared to harmonic scalpel.
\end{abstract}

Key words: Laparoscopy. Nephrectomy. Electrocoagulation. Harmonic scalpel. Necrosis.

\section{RESUMO}

Objetivo: Estabelecer um modelo experimental de nefrectomia parcial laparoscópica (NPL) em ratos e analisar as alterações morfológicas no parênquima renal utilizando-se bisturi elétrico e harmônico. Métodos: Foram utilizados 40 ratos Wistar, distribuídos em dois experimentos com 20 ratos cada: experimento I, NPL utilizando-se de bisturi elétrico e subdividindose os ratos em grupos A e B; experimento II, NPL realizada com bisturi harmônico e subdividindo-se os ratos em grupos C e D. Os animais dos grupos A e C foram sacrificados após a cirurgia para a remoção do rim operado e estudo das seguintes variáveis: necrose e degeneração. Nos grupos B e D a laparotomia para a retirada do rim operado foi após o décimo quarto dia de pós-operatório para a análise da cicatriz fibrosa. Resultados: O bisturi elétrico provocou uma necrose e cicatriz fibrosa mais extensas em relação ao bisturi harmônico ( $\mathrm{p}=0.0002 \mathrm{e} \mathrm{p}=0.0068$ respectivamente). Em relação a variável degeneração, não houve diferença entre os tipos de bisturis $(p=0.1267)$. Conclusões: NPL em ratos é um modelo experimental adequado e factível. O bisturi elétrico causa danos teciduais mais intensos no rim operado quando comparado com o bisturi harmônico.

Descritores: Laparoscopia. Nefrectomia. Eletrocoagulação. Bisturi harmônico. Necrose. 


\section{Introduction}

Radical nephrectomy is the treatment of choice for localized renal cell carcinoma. However, studies suggest that the partial nephrectomy presents cure indexes similar to those obtained by radical surgery. This technique is indicated mostly for patients with damaged contralateral kidney or with a small (less than $4 \mathrm{~cm}$ ) localized tumor, and normal contralateral kidney ${ }^{1,}$. Although the laparoscopic nephrectomy has been well established and accepted by the urologic community, the laparoscopic partial nephrectomy (LPN) has not gained the same popularity due to the problems associated with hemostasia of the renal parenchyma and risk of urinary fistulas ${ }^{2}$. Resulting from initial reports of high rates of complications and conversion to open surgery, several researchers have developed techniques to facilitate the procedure $^{3,4}$. It is observed that the greatest concern involves hemostasia of the renal parenchyma during LPN, and for such, different instruments, techniques, and sources of energy have been investigated, concluding that there is no consensus regarding the best method $^{5}$. However, very little has been studied regarding the effect of the procedures in remnant renal parenchyma ${ }^{6,7}$. Studies in animal models have been performed preferentially in medium and large animals. However, due to the low cost and ease providing and maintaining, the rat seems to be an ideal model for laparoscopic studies ${ }^{8}$. Despite these advantages, we found no current data on LPN in rats. With this experiment we propose to establish an experimental model of partial laparoscopic nephrectomy in rats, as well as to compare the morphological changes in the remnant renal tissue after LPN with the electric cautery and harmonic scalpel.

\section{Methods}

Forty Wistar Novergicus albino male rats, 20 weeks old, weighting more than 350 grams were used. Throughout the study period, the provisions set by the "Colégio Brasileiro de Experimentação Animal" (COBEA) about the breeding and use of animals for teaching and research activities were followed. Supporting the characteristics of the experiment, the animals were randomly distributed into two designated groups: Experiment I (20 rats) and Experiment II (20 rats). In Experiment I polar inferior left LPN with an electric cautery was performed and the rats were then subdivided into Group A (10 rats) and Group B (10 rats). In Experiment II LPN was performed with an harmonic scalpel and the rats were subdivided into Group C (10 rats) and Group D (10 rats). The animals in groups $\mathrm{A}$ and $\mathrm{C}$ were sacrificed on the day of surgery, and then analyzed for the variables of degeneration and necroses. The animals of groups $B$ and $\mathrm{D}$ were sacrificed 14 days after the procedure and then the size of the fibrous scarring was analyzed.

\section{Operatory technique}

The anesthesia method was an intraperitoneal injection of sodium tiopental in a dose of $65 \mathrm{mg} / \mathrm{Kg}$, shortly after, the animals were positioned in dorsal decubitus on a cork board, with the four limbs fixed to the surgical table. A complete manual tricotomy of the ventral side was performed, followed by antisepsis with gauze embedded in $70 \%$ alcohol. Pneumoperitonium was achieved with a Veress needle positioned in a mean line with the abdomen, two thirds below the xiphoid process, making an incision of $5 \mathrm{~mm}$ (Figure 1$)^{9-11}$. The cavity was then inflated with $\mathrm{CO} 2$, until reaching a maximum pressure of $5 \mathrm{mmHg}^{12}$. After removing the needle the skin was held back with hemostatic tweezers and a trocar was inserted, thereby introducing the optic $0^{\circ}$ cystoscope (Storz ${ }^{\circledR}$ Hopkins II). Under transillumination, the other two incisions of $5 \mathrm{~mm}$ were made, the first in the lower left abdominal quadrant and the second in the mean line of the abdomen (between the xiphoid process and the optic trocar), into which the trocars were introduced $(5 \mathrm{~mm})$ for the dissection and pressure tweezers and the electric cautery (Electrosurgical Generator SS-200 WEM ${ }^{\circledR}$ ) or harmonic scalpel (Ultracision $₫$ - Ethicon Endo-Surgery) (Figure 2). After inspecting the abdominal cavity, the colon and small intestine were pulled downward and medially and then the left kidney was detached releasing the retroperitoneal fat. The ureter was identified, the kidney secured by the pressure tweezers was positioned in its third midsection, at which point the resection of the inferior renal pole was initiated (Figure 3). In Experiment I the electric cautery was used connected to scissors, maintained at level 5 (0-10 from the scale on the panel of the apparatus), in a blend cut. In Experiment II the harmonic scalpel was used, maintained at level 2 (function VAR) with the internal blade in the cutting position. After the partial nephrectomy, a revision of hemostasia was done and the trocars were removed under view. The pneumoperitoneum was then released and the portals were sutured with a mononylon line 3-0. In groups $\mathrm{A}$ and $\mathrm{C}$ a median xiphopubic laparotomy was performed immediately after the end of the laparoscopic procedure to remove the operated kidney and the animals were sacrificed with a high dose of intraperitoneal sodium tiopental. The animals in groups B and D had free access to water and food after the laparoscopic procedure, and were maintained alive for a period of 14 days, after which they underwent a laparotomy to remove the operated kidney and were then also sacrificed with a high dose of Tiopental. 


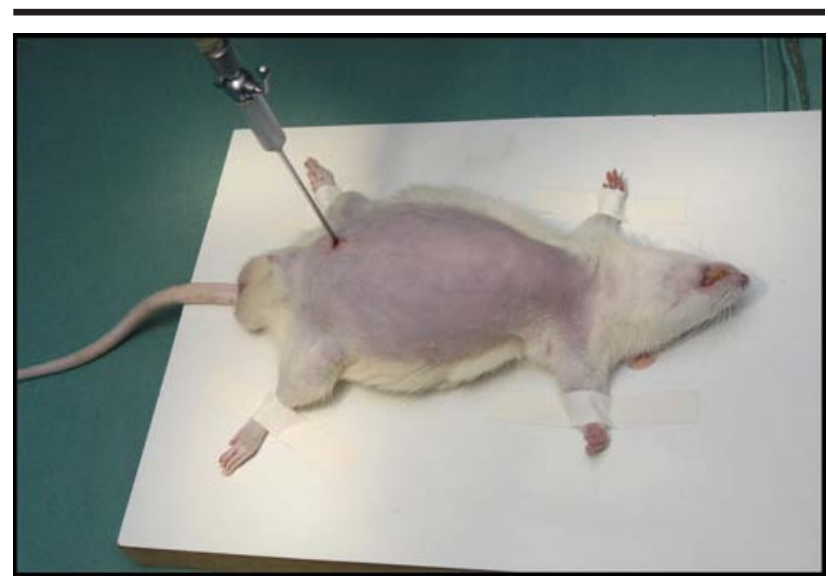

FIGURE 1 - Needle of Veress and pneumoperitonium installed

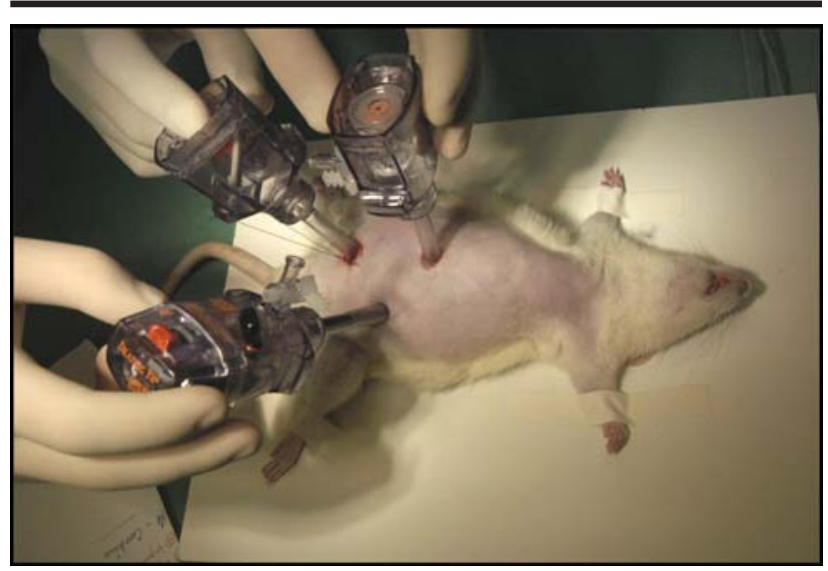

FIGURE 2 - Positioning and fixing of trocars

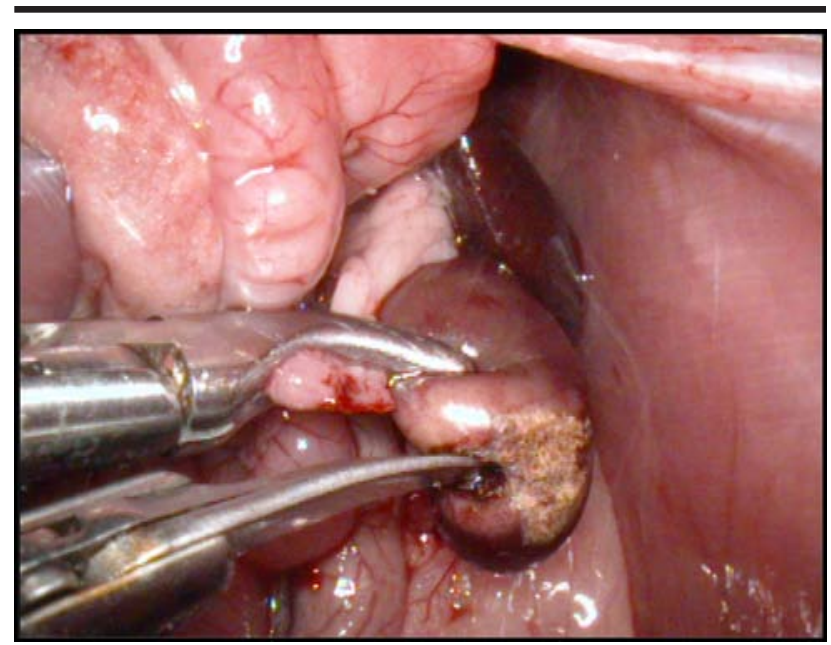

FIGURE 3 - Section of renal inferior pole

\section{Histological analysis}

After removal of the kidney, it was sectioned longitudinally on its anti-hilar edge, for adequate fixation. The organ was conditioned in an individual vial containing a $10 \%$ formalin solution. After fixing, the kidney samples containing the site of the LPN underwent standard histological processing. The samples prepared in this manner allowed for analysis of the area of the partial nephrectomy, alterations in the cortex and adjacent medulla, and alterations of the pielocalicial system. Thereafter, the samples underwent microtomy with cuts in series of four micrometers and colored in hematoxilin and eosin and PAS coloring with Gomori enzymatic and trichromic digestion. The morphological parameters of the histological cuts were the following: necroses, degeneration and width of fibrous scarring. The presence and or absence of these parameters were evaluated, and in the presence, the extent of alteration was noted in millimeters. The area of necrosis was identified by the alteration of tissues, characterized by the trace amorphs and eosinophils of the cell structure which appeared contracted and coagulated. The area of degeneration was defined by analyzing the epithelium of the rounded tubule coverings, which cells appeared to have increased in size, with granular and pale cytoplasms, at times finely spaced, nuclei with vesicles, and a reduction in tubular lumen. The area of fibrosis was identified by the substitution of renal tissue for fibrous conjunctive tissue containing proliferated fibroblasts and deposition of fibrilar and eosinophilic matrix of the collagen. Regarding the variables of necroses and degeneration, five measurements were taken in a random fashion, and the mean was considered for statistical purposes. In fibrous scarring, due to the pyramid format, the area of greatest width was measured. The measurements were taken by computerized morphometry the software Image ProPlus, v. 4.5.1.23, The Proven Solution, by Media Cybernetics Inc. (USA); the imaging was done by Sony CCD Íris, Color Vídeo Câmera (Sony Inc., Japan), attached in trinocular microscopy Olympus BX51 (Olympus, Japan).

\section{Statistical analysis}

The variables analyzed were expressed as means and standard deviations, and for comparisons of the groups the student t-test was used for independent samples, taking into consideration the homogeneity or not of the variances, verifying the presupposition of normality. In all the tests a value of $\mathrm{p}<0.05$ was considered statistically significant.

\section{Results}

For each of the variables, the null-hypothesis was tested for which the mean for the animals of Experiment I is equal to the mean for the animals of Experiment II, versus the alternative hypothesis of different means. Table 1 shows the results of the means, standard deviations, and the $\mathrm{p}$ values obtained from the statistical tests for the three variables analyzed. 
TABLE 1 - Results of means, standard deviations and p-values for the variables: necrosis, degeneration and width of fibrous scarring

\begin{tabular}{lccc}
\hline VARIABLE & $\begin{array}{c}\text { EXPERIMENTI } \\
\text { ( ELECTRIC } \\
\text { BISTOURY) }\end{array}$ & $\begin{array}{c}\text { EXPERIMENTOII } \\
\text { (HARMONIC } \\
\text { BISTOURY })\end{array}$ & Pvalue $^{(\mathbf{1})}$ \\
\hline Necrosis $(\mathrm{mm})$ & Mean \pm SD & Mean \pm SD & $\mathbf{0 . 0 0 0 2}$ \\
Degeneration $(\mathrm{mm})$ & $0.78 \pm 0.22$ & $0.40 \pm 0.10$ & 0.1267 \\
Width of fibrous scarring $(\mathrm{mm})$ & $1.16 \pm 0.22$ & $1.30 \pm 0.16$ & $\mathbf{0 . 0 0 6 8}$ \\
\hline
\end{tabular}

(1) Student $-t$ test.

\section{Discussion}

LPN, although feasible, presents as the principal difficulty, parenchymal hemostasia, causing excessive bleeding and consequently the conversion of this procedure for open surgery ${ }^{13}$. As well as hemorrhage, other associated complications include urinary fistula, vascular lesion, intestinal lesion and in the case of LPN for tumors, local recurrence ${ }^{14}$. Studies have been done with the objective of combining the benefits of the partial nephrectomy and the laparoscopy in treatment of renal tumors in humans and animal models. The study by Kaouk et al. showed that the rat is an ideal model for research in laparoscopy, due to the low cost and ample data ${ }^{8}$. Giuffrida et al. demonstrated that the splenectomy and the laparoscopic nephrectomy in rats are technically feasible and can be utilized in experimental studies to evaluate the applicability of the laparoscopy in oncological treatment ${ }^{12}$. The lack of method consistent for obtaining hemostasia remains as the major obstacle for LPN in becoming a routine procedure in the urologic field. For this to occur, it is necessary to develop effective and simple techniques, which allow the preservation of the renal adjacent parenchyma ${ }^{6}$. Electrosurgical energy is the most commonly used in surgeries since the introduction by William Bowie of the first electrosurgical instrument using high frequency radio waves ${ }^{16}$. In our study, the electric cautery used (Electrosurgical Generator SS-200 WEM $®$ ), worked on a frequency of $480000 \mathrm{~Hz}$, in a blend function. Concerning the ultra-sonic energy, there are two types available for surgical application: CUSA $®$ (Cavitron Ultrasonic Surgical AspiratorValleylab, Boulder, CO) and the harmonic scalpel. The last one utilizes a titanium blade which vibrates 55500 cycles per second, and in contact with tissue, denatures protein forming a hemostatic coagulate ${ }^{3}$. There are very few studies that evaluate the local or systemic effects of LPN, this being our motivation for performing this experimental study ${ }^{4,6,7,17}$. Tulikangas et al. compared the macroscopic effects and histological causes for laparoscopic lesions utilizing four different sources of energy (electric monopolar and bipolar cautery, harmonic scalpel, and $\mathrm{CO}_{2}$ laser) in the ureter, bladder and rectum of pigs. The results showed that the energy sources utilized damage the tissues in different manners, however, the electric cautery caused greater tissue damage than the others ${ }^{18}$. In the study of Barret et al. LPN which was performed in pigs comparied three techniques of hemostasia (electric bipolar, argonic, and harmonic scalpel).
The tissue lesions induced during the coagulation of the renal parenchyma were superficial and the adjacent tissue remained preserved. There was no statistical significant difference in relation to necroses in the three groups studied $(p=0.185)$. The authors showed that, due to the necessity of greater time of tissue contact with the harmonic scalpel to obtain hemostasia, the tissue damage observed was compared to the tissue from the electric bistoury ${ }^{6}$. This was not observed in our study despite of section time being greater in the animals using harmonic scalpel, the width of the necrosis in this group was smaller. Jackman et al. attempted to determine if the extent of renal resection with the harmonic scalpel would have an influence on obtaining parenchymal hemostasia. They performed thirty LPN in pigs, establishing three types of resection: peripheral biopsy (type 1), polar superior or inferior (type II), and heminephrectomy (type III). After each procedure a laparotomy was performed to evaluate the bleeding. According to the authors, the main limitation of this study was the non-preservation of the live animals in order to analyze the alterations that occurred in the chronic phase. They concluded that a heminephrectomy should not be performed with a harmonic scalpel due to the risk of hemorrhage and consequent necessity of conversion to open surgery ${ }^{4}$. In the present study, morphological analysis of the remnant kidneys was performed in the acute phase and the chronic phase. In the acute phase the width of the necrosis and degeneration was evaluated in group A (electric cautery) and in group C (harmonic scalpel). In the chronic phase the width of the fibrous scarring was evaluated in group $\mathrm{B}$ (electric cautery) and in group $\mathrm{D}$ (harmonic scalpel). As to necroses, it was observed that group A presented a mean depth $(0.78 \mathrm{~mm})$ greater than that of group $\mathrm{C}$ $(0.40 \mathrm{~mm})$, a statistically significant difference $(p=0.0002)$. Addonizio and Choudhury performed open partial nephrectomy in an experimental model, utilizing CUSA and the electric cautery. They demonstrated that the depth of the lesion in the parenchyma caused by the electric cautery was three times greater than that caused by $\mathrm{CUSA}^{19}$. Regarding degeneration, there was no statistically significant difference $(p=0.1267)$ between group $A(1.16 \mathrm{~mm})$ and group $\mathrm{C}(1.30 \mathrm{~mm})$. The hidropic degeneration and the vacuolar degeneration which identify histologically this reversible phenomenon, are alterations that do not manifest in the early stage of injury, and they are present only in cells which metabolic function has already a certain degree of damage ${ }^{20}$. Shortly after the acute 
phenomenon of injury that results in necroses, tissue repair begins, the final result being fibrous scarring. The extent of this repair phenomenon is related to several factors, specially the spread of necroses ${ }^{22}$. In this study, the width of the fibrous scarring was greater in the group of animals which underwent LPN with an electric cautery $(\mathrm{p}=0.0068)$, and correlated with a greater width of necroses in this group. Although the histopathological effects of the section by the harmonic scalpel in the remnant renal tissue of a lesser degree when compared to the electric cautery, studies still remain incomplete regarding ultra-structural, biochemical and immunological effects, and should be further elaborated in future studies utilizing this experimental model.

\section{Conclusions}

Laparoscopic partial nephrectomy, in rats, is an adequate and feasible experimental model. The electric cautery caused greater damage to remnant renal tissue when compared to the harmonic scalpel.

\section{References}

1. Lee CT, Katz J, Shi W, Thaler HT, Reuter VE, Russo P. Surgical management of renal tumors $4 \mathrm{~cm}$ or less in a contemporary cohort. J Urol. 2000;163:730-6.

2. Clayman RV, Kavoussi LR, Soper NJ, Dierks SM, Meretyk S, Darcy MD, Roemer FD, Pingleton ED, Thomson PG, Long SR. Laparoscopic nephrectomy: initial case report. J Urol. 1991;146:278-82.

3. Elashry OM, Wolf JS Jr, Rayala HJ, McDougall EM, Clayman RV. Recent advances in laparoscopic partial nephrectomy: comparative study of electrosurgical snare electrode and ultrasound dissection. J Endourol. 1997;11:15-22.

4. Jackman SV, Cadeddu JA, Chen RN, Micali S, Bishoff JT, Lee BR, Moore RG, Kavoussi LR. Utility of the harmonic scalpel for laparoscopic partial nephrectomy. J Endourol. 1998;12:441-4.

5. Ogan K, Cadeddu JA. Laparoscopic partial nephrectomy: a procedure in evolution. Braz J Urol. 2002;28:184-91.

6. Barret E, Guillonneau B, Cathelineau X, Validire P, Vallancien G. Laparoscopic partial nephrectomy in the pig: comparison of the three hemostasis techniques. J Endourol. 2001;15:307-12.
7. Matthews BD, Pratt BL, Backus CL, Kercher KW, Mostafa G, Lentzner A, Lipford EH, Sing RF, Heniford BT. Effectiveness of the ultrasonic coagulating shears, ligasure vessel sealer, and surgical clip application in biliary surgery: a comparative analysis. Am Surg. 2001;67:901-6.

8. Kaouk JH, Gill IS, Meraney AM, Desai MM, Carvalhal EF, Fergany AF, Sung GT. Retroperitoneal minilaparoscopic nephrectomy in the rat model. Urology. 2000;56:1058-62.

9. Berguer R, Gutt C, Stiegmann GV. Laparoscopic surgery in the rat: description of a new technique. Surg Endosc. 1993;7:345-7.

10.Sandoval BA, Sulaiman TT, Robinson AV, Stellato TA. Laparoscopic surgery in a small animal model: a simplified technique of retroperitoneal dissection in the rat. Surg Endosc. 1996;10:925-7.

11. Bouvy ND, Marquet RL, Hamming JF, Jeekel J, Bonjer HJ. Laparoscopic surgery in the rat: beneficial effect on body weight and tumor take. Surg Endosc. 1996;10:490-4.

12. Giuffrida MC, Marquet RL, Kazemier G, Wittich P, Bouvy ND, Bruining HA, Bonjer HJ. Laparoscopic splenectomy and nephrectomy in a rat model: description of a new technique. Surg Endosc. 1997; 11:491-4.

13.Beck SD, Lifshitz DA, Cheng L, Lingeman JE, Shalhav AL. Endoloop-assisted laparoscopic partial nephrectomy. J Endourol. 2002;16:175-7.

14.MeraneyAM, Samee AA, Gill IS. Vascular and bowl complications during retro peritoneal laparoscopic surgery. J Urol. 2002;168:1941-4.

15.Shanberg AM, Zagnoev M, Clougherty TP. Tension pneumothorax caused by the argon beam coagulator during laparoscopic partial nephrectomy. J Urol. 2002;168:2162.

16.Soderstrom RM. Electrosurgical injuries during laparoscopy: prevention and management. Curr Opin Obstet Gynecol. 1994;6:248-50.

17.Landman J, Kerbl K, Rehman J, Andreoni C, Humphrey PA, Collyer W, Olweny E, Sundaram C, Clayman RV. Evaluation of a vessel sealing system, bipolar electrosurgery, harmonic scalpel, titanium clips, endoscopic gastrointestinal anastomosis vascular staples and sutures for arterial and venous ligation in a porcine model. J Urol. 2003;169:697-700.

18. Tulikangas PK, Smith T, Falcone T, Boparai N, Walters MD. Gross and histologic characteristics of laparoscopic injuries with four different energy sources. Fertil Steril. 2001;75:806-10.

19. Addonizio JC, Choudhury MS. Cavitrons in urologic surgery. Urol Clin North Am. 1986;13:445-54.

20.Mitchell RN, Cotran RS. Tissue repair: cell regeneration and fibrosis. In: Kumar V, Cotran RS, Robbins SL. Robbins basic pathology. 7ed. Philadelphia: W.B. Saunders; 2003. p.61-78.

\section{Correspondence:}

Fernando Meyer

Av. Batel, 1230/703

80420-907 Curitiba - PR Brazil

Phone/Fax: (55 41)3015-0303

fmeyer@onda.com.br
Conflict of interest: none Financial source: none

Received: November 23, 2006

Review: December 18, 2006

Accepted: January 15, 2007

\section{How to cite this article:}

Meyer F, Ioshii SO, Chin EWK, Esser DM, Marcondes RT, Patriani AH, Pimpão BF. Laparoscopic partial nephrectomy in rats. Acta Cir Bras. [serial on the Internet] 2007 Mar-Apr;22(2). Available from URL: http://www.scielo.br/acb 